\title{
Sprawozdanie z XI Usteckich Dni Onkologicznych
}

W dniach 5-7 września 2014 roku odbyły XI Usteckie Dni Onkologiczne, organizowane przez zespół Oddziału Chirurgii Ogólnej, Naczyniowej i Onkologicznej Wojewódzkiego Szpitala Specjalistycznego im. Janusza Korczaka w Słupsku. Uczestników gościł malowniczy nadmorski kurort Ustka, a obrady odbywały się w Hotelu Royal Baltic.

Tematami przewodnimi tegorocznych Dni były: „Genetyka w służbie chirurgii onkologicznej" oraz „Powikłania chirurgiczne i onkologiczne leczenia nowotworów", a sesji pielęgniarskiej „Rak piersi — współczesne wyzwania i nadzieje". Patronat nad Sympozjum objęły: Polskie Towarzystwo Chirurgii Onkologicznej, Towarzystwo Chirurgów Polskich, Polskie Towarzystwo Patologów, Konsultant Krajowy ds. Chirurgii Onkologicznej prof. Krzysztof Herman, Konsultant Krajowy ds. Chirurgii Ogólnej prof. Grzegorz Wallner oraz Redaktor Naczelny pisma Nowotwory Journal of Oncology prof. Edward Towpik, a patronat honorowy - Marszałek województwa pomorskiego Mieczysław Struk, ks. Edward Dajczak — Biskup diecezjalny, Jerzy Karpiński — Dyrektor Wydziału Zdrowia PCZP Gdańsk oraz Prof. Andrzej Kułakowski.

Wieczorem w przeddzień Konferencji odbył się„,Wieczór Macedoński” w „Dolinie Charlotty”.

Nowością tegorocznego spotkania było równoczesne odbywanie się sesji pielęgniarskiej oraz lekarskiej. Obrady dla pielęgniarek odbywały się pierwszego dnia w sali wykładowej Akademii Pomorskiej w Słupsku; tematami przewodnimi były: profilaktyka i diagnostyka oraz nowoczesne metody leczenia chirurgicznego chorych na raka piersi. Drugiego dnia w sali wykładowej Hotelu Royal Baltic omawiano różne aspekty opieki pielęgniarskiej w leczeniu raka piersi.

Część lekarska rozpoczęła się warsztatami zaawansowanych technik małoinwazyjnych w chirurgii onkologicznej. Pokazano zabiegi z wykorzystaniem laparoskopii w operacji raka odbytnicy.

Kolejnym punktem były oficjalna inauguracja Sympozjum oraz wystąpienia zaproszonych gości. Wykład inauguracyjny wygłosił Prof. Nagy Habib z Hammersmith Hospital, Imperial College w Londynie - dotyczył zastosowania ablacji RFA w onkologii. Później odbyły się warsztaty nt. zastosowania termoablacji RFA, w trakcie których Prof. Habib prezentował nóż własnej konstrukcji oraz wskazania do jego zastosowania w praktyce. Ostatnia sesja, prowadzona przez Prof. Jana Lubinskiego, poświęcona była genetyce. Uczestnicy dyskutowali na temat informacji, jakich potrzebuje chirurg od genetyka oraz na temat chorób genetycznych w onkologii i ich leczenia chirurgicznego.

Drugi dzień rozpoczął się od wręczenia medali,„Usteckich Dni Onkologicznych"zasłużonym w organizacji Konferencji Prof. Pawłowi Lampe oraz Prof. Piotrowi Rutkowskiemu. Tego dnia odbyły się 3 sesje oraz 2 wykłady sponsorowane. Pierwsza sesja, pod patronatem Prezesa Towarzystwa Chirurgów Polskich, dotyczyła powikłań chirurgicznego i onkologicznego leczenia nowotworów. Kolejno uczestnicy omawiali problemy związane z powikłaniami leczenia chirurgicznego w obrębie jamy brzusznej, przewodu pokarmowego, tkanek miękkich oraz powikłania technik małoinwazyjnych w chirurgii. Ostatnim wykładem była prezentacja Prezesa Polskiego Klubu Koloproktologicznego prof. Marka Szczepkowskiego, który zaprezentował polski konsensus w sprawie stomii protekcyjnej. Kolejnym punktem tego dnia były 2 wykłady sponsorowane dotyczące bólu neuropatycznego oraz zakażeń jako powikłań interwencji chirurgicznej w leczeniu nowotworów. Na koniec odbyła się sesja Wydawnictwa Lekarskiego PZWL, połączona z promocją książki „Powikłania chirurgii onkologicznej, występowanie - leczenie" pod redakcją prof. Andrzeja Szawłowskiego. W 11 wykładach omawiano potencjalne powikłania w chirurgii, a w szczególności specyfikę powikłań w chirurgii onkologicznej z podziałem na poszczególne układy oraz rodzaje zabiegów.

Wydarzeniem, które będzie miało niewątpliwie wielki wpływ na dalsze losy Usteckich Dni Onkologicznych, było porozumienie Prezesów Towarzystwa Chirurgów Polskich i Polskiego Towarzystwa Chirurgii Onkologicznej o wspólnym organizowaniu tej cyklicznej Konferencji w przyszłości, już od następnego roku. Przewodniczącymi Komitetu Naukowego będą odtąd obaj urzędujący prezesi, co wpłynie zarówno na podniesienie rangi Konferencji, jak i zacieśnienie współpracy obu Towarzystw, a w konsekwencji — pomoże w wypracowaniu wspólnej strategii leczenia chirurgicznego nowotworów.

Dr n. med. Zoran Stojcev

Oddział Chirurgii Ogólnej, Naczyniowej i Onkologicznej

Wojewódzki Szpital Specjalistyczny im. Janusza Korczaka w Słupsku e-mail:stojcev@wp.pl 